\title{
わい性拈よび半わい性台木を利用したリンゴ“スターキング・デリシャス’樹の 根成長に及ぼす栽植密度の影響
}

\author{
黒田治之*・千葉和彦 \\ 農業・生物系特定産業技術研究機構北海道農業研究センター 062-8555 札幌市豊平区羊ヶ丘
}

Effect of Planting Density on Root Growth in 'Starking Delicious' Apple Trees Grafted on Dwarfing and Semi-dwarfing Rootstocks

Haruyuki Kuroda* and Kazuhiko Chiba

National Agricultural Research Center for Hokkaido Region, NARO, Hitsujigaoka, Toyohira-ku, Sapporo 062-8555, Japan

\begin{abstract}
The effect of planting density on root growth was studied in 11 to 13-year-old 'Starking Delicious' apple trees (Malus domestica Borkh.) grafted on M.9, M.26, M.7 and MM.106 without pruning. At the 330 trees/ ha plot the root system was composed of major lateral roots with few vertical sinkers, but at the 3178 trees/ ha plot it was mainly of lateral roots. The root spread decreased as planting density increased, but the degree of intermingling of adjacent root systems increased. At the 3178 trees/ha plot the adhesion phenomenon between adjacent root systems was observed. The root/canopy spread ratio decreased as planting density increased, indicating that root spread was more strongly inhibited than canopy spread by an increase of plant density. The distribution ratio of root weight with depth was not affected by planting density, but the root dry weight per tree in each depth decreased as planting density increased, particularly in the major $(>15 \mathrm{~mm})$ root of the $0-30 \mathrm{~cm}$ layer. On all rootstocks, the root dry weight per tree (R) decreased as planting density $(\rho)$ increased. The relationship between $\mathrm{R}$ and $\rho$ could be represented by the reciprocal equation: $1 /$ $R=A_{R} \rho+B_{R}-(1)$, where $A_{R}$ and $B_{R}$ are the coefficients depending on the tree age and rootstock. The relationship between root dry weight per tree $(R)$ and trunk cross-sectional area $(\theta)$ could be represented by the relative growth equation with $\mathrm{h}>1: \mathrm{R}=\mathrm{H} \theta^{\mathrm{h}}-(3)$, where $\mathrm{H}$ is the coefficient depending on rootstock. The root dry weight per hectare in each depth increased as planting density increased, and the increase was markedly in the fine $(<1 \mathrm{~mm})$ and small $(1-5 \mathrm{~mm})$ roots. On all rootstocks, the root dry weight per hectare $(\overline{\mathrm{R}})$ increased as planting density $(\rho)$ increased. The relationship between $\bar{R}$ and $\rho$ well fitted the theoretical equation obtained from $R=H \theta^{\mathrm{h}}$ (equation 3), $1 / \theta=A \rho+B$ (equation 4) and $\bar{R}=R \rho$ (equation 5$): \bar{R}=H \rho /(A \rho+B)^{h}-(6)$, where $\mathrm{A}$ and $\mathrm{B}$ are the coefficients depending on the tree age and rootstock. The planting density $\left(\rho_{\overline{\mathrm{R}} \mathrm{pk}}\right)$ that $\overline{\mathrm{R}}$ becomes the maximum is given by $\rho_{\overline{\mathrm{R} p k}}=\mathrm{B} / \mathrm{A}(\mathrm{h}-1)-(7)$. These results indicated that root dry weight per hectare increases as planting density increases, while it starts to decrease at the $\rho_{\overline{\mathrm{R} p k}}$.
\end{abstract}

Key Words: apple trees, dwarfing and semi-dwarfing rootstocks, logistic theory, planting density, root growth.

\begin{abstract}
緒言
著者らは既報（黒田・千葉，1999, 2000, 2004; 黒田ら， 1996，1997）に执いて，わい性抢よび半わい性台木を利 用した“スターキング・デリシャス’リンゴ樹 (Malus domestica Borkh.) に打ける幹断面積, 果実収量, 葉成長, 花芽形成および枝幹成長と栽植密度の関係について検討 し，それらの関係が植物成長に関するロジスチック理論 (Shinozaki・Kira, 1956, 1961) によって記述できることを
\end{abstract}

2004 年 12 月 1 日受付. 2005 年 7 月 8 日受理.

* Corresponding author (E-mail: kurodah@agri.kagoshima-u.ac.jp). 現在 : 鹿児島大学農学部附属農場 890-0065 鹿児島市郡元.
明らかにした，しかし，わい性および半わい性台木利用 リンゴ樹に沶ける密度効果の全体像を明らかにするため には, 地下部における密度効果の解明が必要である。 Atkinson ら（1976）はリンゴ'ゴールデン・デリシャ ス’/M.9を用いて, $(2.4 \mathrm{~m})^{2},(1.2 \mathrm{~m})^{2},(0.6 \mathrm{~m})^{2},(0.3 \mathrm{~m})^{2}$ の 4 段階で栽植密度試験を行い, 1 樹当たり根重は栽植密 度の増加に伴って減少したが，根密度は増加したことを 報告している。また, Kaufmann ら（1972）はオレンジロ シントン・ネーブル’を用いて, $2.7 \times 4.5 \mathrm{~m} \sim(6.6 \mathrm{~m})^{2}$ の 間で 9 段階の栽植密度試験を行い, 根密度や隣接樹根と の交差深度が栽植密度の増加に伴って増加すること明ら かにし, Boswell ら (1975) もオレンジワシントン・ネー ブル’を用いて，222～890 樹/ha の間で 5 段階の栽植密 
度試験を行い, 栽植密度の増加に伴って根系幅や根の太 さおよび長さが減少したことを報告している。しかし， 根の成長と栽植密度の関係をロジスチック理論に基づい て解析した報告は見当たらない。它し，根成長と栽植密 度の関係がロジスチック理論によって記述できれば，根 成長の生態学的特性はもとより, 根成長が関係する多く の成長現象をロジスチック理論の立場から解析できるよ らになるものと考光られる。

そこで，本試験では，わい性拈よび半わい性台木に接 ぎ木したリンゴ‘スターキング・デリシャス’樹の根成長 に及ぼす栽植密度の影響を調査し，根の成長に対する口 ジスチック理論の適合性について検討した。

\section{材料および方法}

\section{1. 栽植密度試験圃，樹体管理および肥培管理}

1975 年 5 月に M.9, M.26, M.7 拈よび MM.106 台木に 接ぎ木したリンゴ品種“スターキング・デリシャス’ 1 年 生苗木を等比級数 $\left(\mathrm{L}_{\mathrm{n}}=\alpha+\mathrm{a}\left(1-\mathrm{r}^{\mathrm{n}}\right) /(1-\mathrm{r})\right.$ ，ただし， $\alpha=9.55, a=1.75, r=7 / 6, n=0 \sim 9$ ) 飞従って放射状 (中心 角 $9^{\circ}, 40$ 列）に栽植した。栽植密度は，M.9 と M.26 台 木樹では 453, 623, 858, 1185, 1642, 2281, 3178 樹/ha の 7 段階, M.7 と MM.106 台木樹では 330, 453, 623, 858, 1185, 1642, 2281, 3178 樹/ha 98 段階とし, 各密度区は 1 密度 区 4 樹 2 反復で，計 8 樹をもって構成した（黒田ら, 1996).

樹形は主幹形とし，剪定は徒長枝の剪去程度で，注淁 無剪定状態とした. 摘果は 4 頂芽 1 果を基準に行った.

土壤管理は定植後, 樹齢 4 年生までは清耕法とし， 5 年生以降は除草剂散布による裸地無耕起とした。肥料は 4 年生までは無施肥としたが, $5 \sim 7$ 年生の 3 年間は 1 ha 当たり成分量で $\mathrm{N}: 46 \mathrm{~kg}, \mathrm{P}_{2} \mathrm{O}_{5}: 33 \mathrm{~kg}, \mathrm{~K}_{2} \mathrm{O}: 50 \mathrm{~kg}$ を, 7 年 生以降は $\mathrm{N}: 62 \mathrm{~kg}, \mathrm{P}_{2} \mathrm{O}_{5}: 40 \mathrm{~kg}, \mathrm{~K}_{2} \mathrm{O}: 82 \mathrm{~kg}$ を栽植密度に 関係なく，植栽部の土䁃表面に均等に施用した。

\section{2. 試験戋場の土壤特性}

試験戋場の土㙵は概ね 4 層に区分され，第 1 層は地表 から $18 \mathrm{~cm}$ までの樽前火山灰が混入した腐植に富む黒褐 色 $(10 \mathrm{YR} 2 / 3)$ の埴壤土であり，第 2 層は恵庭火山灰を主 体とする厚さ $37 \mathrm{~cm}$ の腐植が少ない褐色 (10YR4/6) の粘 着性の高い埴袞土であった．深さ 55〜90 cm までの第 3 層は第 2 層と同梯に恵庭火山灰を主体とする褐色 (10YR4/6) の粘土に富む壤土であった。この層は透水性 が悪く，春先の融雪期の一時的な過湿の原因となってい た. 深さ $90 \sim 120 \mathrm{~cm}$ 層は羊蹄，その他の火山灰によっ て構成された褐色＋暗灰黄色 $(10 \mathrm{YR} 4 / 6+2.5 \mathrm{Y} 4 / 2)$ の土壌 硬度 $25 \mathrm{~mm}$ （山中式硬度計）の砂壤土層であった.

\section{3. 根系分布の調査}

1987 年 7 月に, 樹齢 13 年生 M.7 台木樹に打情る 330 , 865 および 3178 樹/ha 区から，それぞれ隣接する 2 樹を 選び，洗掘によって根系分布を調査した。まず，地上部
を除いた後, 洗堀で流れ出す土砂を受けるための溝を, 株から $50 \mathrm{~cm}$ 離し, 樹列横断面に沿って掘った. 次に, その溝から株に向かって奥行き $100 \mathrm{~cm}$ の土壤を地表か ら順次洗堀し (深さ $100 \mathrm{~cm}$ まで), 露出した根を適宜, 写真撮影して樹列横断面の根系分布図を描いた。

根系幅は根系分布図を基に，幹から根の最先端までの 距離を測り，この值から根系分布を左右対称形々仮定し て求めた。根系の交差深度は，(根系幅一樹列間距離）で 計算した．樹冠幅は地上部を切り倒す前に，南北と東西 方向に拡がった樹冠の端から他方の端までを測定し，そ の平均值として求めた.

\section{1樹当たり根重の垂直分布調査}

1 樹当たり根重の垂直分布は, 1986 年の 6 月上旬から 7 月下旬にかけて，前年に生産構造の調査を行った樹齢 11 年生 M.26 台木樹（黒田・千葉，2002）の根部を対象 に，1 樹毎堀り上げて調査した．堀り上げ面積は隣接樹 からの侵入根は抢互いに相殺されると仮定し，樹間に拉 ける中間線と樹列間に括ける中間線で囲まれた四角形と した. 根は地表面から深さ $120 \mathrm{~cm}$ までの土壤を $30 \mathrm{~cm}$ 間 隔で順次掘り上げ，それを篩にかけて採取した。採取し た根は $1 \mathrm{~mm}$ 以下 (細根), 1〜 $5 \mathrm{~mm}$ (小根), $5 \sim 15 \mathrm{~mm}$ (中根), $15 \mathrm{~mm}$ 以上（大根）打よび根幹の 5 段階に分別 乙, 水洗後, $80^{\circ} \mathrm{C}$ の通風乾燥機で 1 週間乾燥させて乾物 重を測定した.

\section{1樹および1 ha 当たりの根重調査}

M.9 と MM.106 台木樹（樹齢 12 年生）の根重は 1987 年の 6 7 月に, M.7 台木樹（13 年生）の根重は 1988 年 の 6 月に，それぞれ前年の 10 月中旬に枝幹重の調査を 行った樹（黒田・千葉，2004）の根部を対象に，1 樹毎 掘り上げて調査した．掘り上げ面積は上述と同様に設定 し, 根は地表から深さ $120 \mathrm{~cm}$ までの土㙵を堀り上げ, そ れを篩にかけて採取した. 採取した根は一括して水洗後, $80^{\circ} \mathrm{C}$ の通風乾燥機で 1 週間乾燥させてから乾物重を測定 した。また，1987 年の 6 月に，13 年生 M.9 台木樹の根 重を同様の方法で調査した. M.26 台木樹に拈ける 1 樹 当たり根重は，垂直分布の値を合計して求めた。

$1 \mathrm{ha}$ 当たり根重は, 1 樹当たり根重に栽植密度（1 ha 当たりの樹数）を乗じて算出した.

\section{6. 幹断面積の調查}

幹断面積は接ぎ木部より $20 \mathrm{~cm}$ 上の幹周を測定し，こ の値から幹の断面を正円形と仮定して計算した。

な扔, 本試験の計数值は, すべて 2 樹の平均值である. 根の各種測定值の栽植密度間差については，一元配置分 散分析を行った後, Duncanの多重検定法によって有意差 を検定した。

\section{結果および考察}

\section{1. 根系分布に及ぼす栽植密度の影響}

樹齢 13 年生 M.7 台木樹の 330, 865 および 3178 樹/ha 


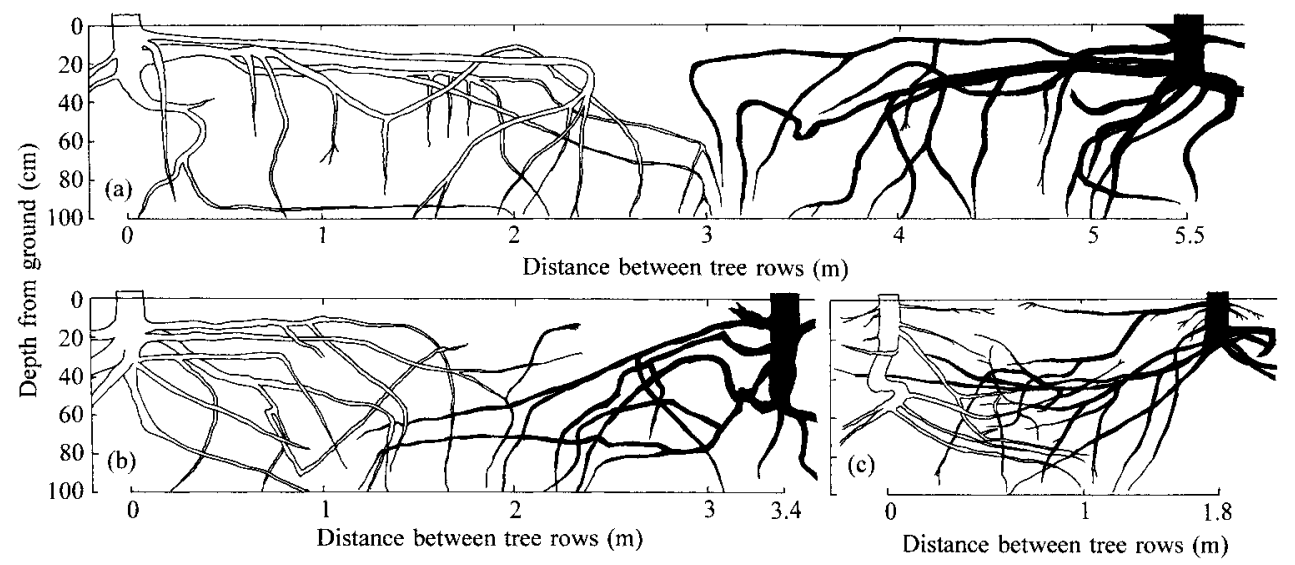

Fig. 1. Typical root system depending on planting density in 13-year-old 'Starking Delicious' apple trees grafted on M.7. (a), 330 trees/ha; (b), 865 trees/ha; (c), 3178 trees/ha.

Table 1. Effect of planting density on root spread, overlapping of root systems, canopy spread and root/canopy spread ratio in 13-year-old 'Starking Delicious' apple trees grafted on M.7.

\begin{tabular}{cccccc}
\hline \hline $\begin{array}{c}\text { Planting density } \\
\text { (trees/ha) }\end{array}$ & $\begin{array}{c}\text { Distance between } \\
\text { tree rows }(\mathrm{m})\end{array}$ & $\begin{array}{c}\text { Root spread }^{\mathrm{z}} \\
(\mathrm{m})\end{array}$ & $\begin{array}{c}\text { Overlapping of }_{\text {root systems }^{\mathrm{y}}(\mathrm{m})} \\
\text { (n) }\end{array}$ & $\begin{array}{c}\text { Canopy spread } \\
(\mathrm{m})\end{array}$ & $\begin{array}{c}\text { Ratio of root } \\
\text { spread to canopy } \\
\text { spread }\end{array}$ \\
\hline 330 & 5.51 & $5.70 \mathrm{a}^{\mathrm{u}}$ & $0.19 \mathrm{a}$ & $6.80 \mathrm{a}$ & $0.84 \mathrm{a}$ \\
858 & 3.41 & $4.45 \mathrm{a}$ & $1.04 \mathrm{~b}$ & $6.25 \mathrm{ab}$ & $0.71 \mathrm{ab}$ \\
3178 & 1.77 & $2.90 \mathrm{~b}$ & $1.13 \mathrm{~b}$ & $4.30 \mathrm{~b}$ & $0.67 \mathrm{~b}$ \\
Significance $^{\mathrm{w}}$ & & $* *$ & $* *$ & $* *$ & $*$ \\
\hline
\end{tabular}

Values are means of two trees.

${ }^{\mathrm{z}}$ Calculated as: $2 \times$ half-root spread measured from Fig. 1 .

${ }^{y}$ Calculated as: root spread - distance between tree rows.

${ }^{x}$ Calculated as: (east-west width + north-south width) $/ 2$.

" Significant at the $5 \%(*)$ and $1 \%(* *)$ by the $\mathrm{F}$ analysis.

" Different letters represent significant differences $(P<0.05)$ by Duncan's multiple range test.

区に打淟型的な根系分布を第 1 図に，根系幅，根系 の交差深度，樹冠幅抏よび根系幅／樹冠幅比を第 1 表に 示した. 330 樹/ha 区の根系は, 根幹から水平に発出した 太い側根と，そこから適度の間隔を拈いて下方に伸長し た下垂根で構成されていた。 また，この区では隣接樹ど らしの根系が接するところで，根が下方に方向を変光， 接触を回避する傾向が認められた。このような結果は, Atkinson ら（1976）も認めて抢り，粗植リンゴ樹に打け る根系分布の一般的様相と考穴られる.

858 樹/ha 区の根系は 330 樹/ha 区とほぼ同様の形態で あったが，その分布域は 330 樹/ha 区より狭く，隣接根 系に対して接触回避する根と, 交差する根が混在してい た. 3178 樹/ha 区では, 水平に伸長した太い側根はみら れなくなり，根幹から発出した側根が隣接根系と相互に 侵入しあい, 深い交差深度と高い根密度の值が得られた。 同様の結果は,リンゴ（Atkinson ら，1976）だけでなく， オレンジ（Boswell ら，1975）でも認められている.

一方， 3178 樹/ha 区では隣接根系間で根が組織的に癒 着する現象が散見された (第 2 図)。根組織の癒着は養 水分吸収の共有を意味することから，癒着で繋がった 2 個体は 1 個体の上らな性質をもつものと思われる．既報

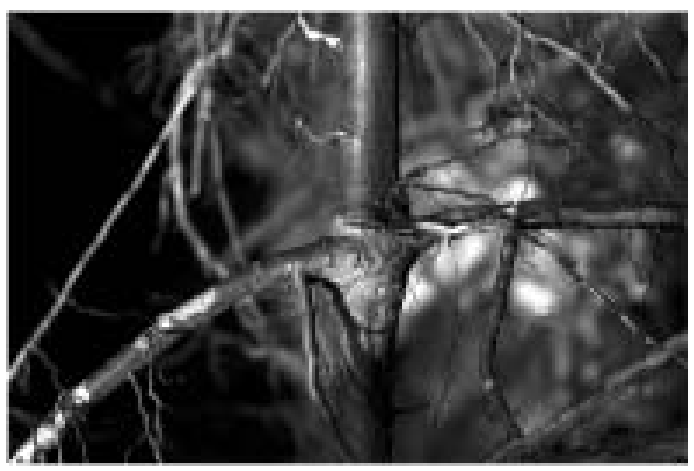

Fig. 2. The tissue fusion between adjacent roots observed at 3178 trees/ha of 13-year-old 'Starking Delicious' apple trees grafted on M.7.

（黒田・千葉，2000）で観察した高密度域における背揃い 現象は，根組織の癒着現象と関連しているのかもしれな い.

以上のように，リンゴ根系は栽植密度の増加に伴って 接触回避，相互侵入そして組織瘉着へと変化することが 認められた。 このことは根成長に打ける反発・融合とい らべき現象であり，リンゴ根系が示す密度効果に打ける 
生態的特性の一つと考えられる. また，根系幅が樹冠幅 と同様に，栽植密度の増加に伴って減少したのは，栽植 密度は水平方向の成長には抑制的に作用するといら密度 効果の性質によるものと考えられる（黒田・千葉, 2004).

なお，本試験では根系幅／樹冠幅比が栽植密度の増加 に伴って低下することが認められ，樹冠幅に比べて，根 系幅の方が栽植密度の抑制を受けやすいことが示され た。このことには言及していないが，Atkinson（1978）が 示した図を見ると，根系幅は栽植密度の増加に伴って樹 冠幅より狭くなって扔り，本試験と同様の結果であると 推測される. 樹冠幅より根系幅の方が密度効果を受けや すいといら事実は，密度効果が根部から始まって樹冠部 に及ぶことを意味するもので, 密度効果現象の一つとし て興味がもたれる.

\section{1樹当たり根重の垂直分布に及ぼす栽植密度の影響}

樹齢 11 年生の M.26 台木樹に打いて調査した 1 樹当 たり根重の垂直分布と栽植密度の関係を第 2 表に示し た。まず，垂直分布比率では，0３0 cm 層に沶いて 72.1 〜78.6\%, 30〜60 cm 層に打いて 15.7〜 16.8\%, 60〜90 cm 層

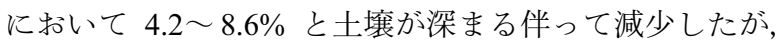
この比率は概して栽植密度に関係なく類似していた。 こ のよらに根重の垂直分布比率は，栽植密度の影響を受け にくいこと，また根系は栽植密度に関係なく，浅根性で あることが明らかとなった。

次に，層毎に根重を比較すると，いずれの層の根重も 栽植密度の増加に伴って減少することが認められた。特 に，0〜30 cm 層での減少量が大きく，3178 樹/ha 区の根
重 $(4.08 \mathrm{~kg})$ は 623 樹/ha 区の $14.19 \mathrm{~kg}$ に比べて, $10.11 \mathrm{~kg}$ の減少を示した。この減少量のうち, 大根の占める量が $4.24 \mathrm{~kg}$ で, 最も大きかった。ささらに，太さ別比率に执い ては, 中根と根幹では栽植密度間に打ける差違は認めら れなかったが, 大根比率は栽植密度の増加に伴って $31.4 \%$ から $25.3 \%$ に減少し, 逆に小・細根比率は増加す る傾向が認められ，根の太さ別構成が栽植密度によって 変化することが示された.

以上のよらに，根系は栽植密度に関係なく浅根性を示 し，また各層の根重は栽植密度の増加に伴って減少し， その減少は 0〜 $30 \mathrm{~cm}$ 層の大根で著しいことが明らかに なった。 これらの結果は，穂積ら（1958）が述べている ように, 占有面積の減少に伴う無機塩類, 炭酸ガス, 光, 土壌水分などの成長要因の供給量制限によって生じたも のと思われるが, これら以外の要因の関与も考えられる. 例えば，低密度域で大根が発達しているのは，独立樹ゆ えに風圧に対する耐性が必要なためであり，高密度域で 太い根が少ないのは，密植による減風効果によって倒伏 防止に関わる太い根の必要性が低下するためと考察でき る. 密度効果は個体を取り巻く全ての環境要因に対する 適応現象と解釈すべきであろら。

なお，リンゴ樹の根群分布は土䁃や台木によって差違 を生じるが (Coker, 1958)，整枝剪定によっても変化する ことが知られている(三浦，1950)。本試験において無剪 定状態としたのは，栽植密度の影響が剪定によって摚乱 されてしまい，密度効果の実態が浮かび上がってこない ことが懸念されたからである。剪定や間伐を行ら実際栽

Table 2. Effect of planting density on root distribution in 11-old-year 'Starking Delicious' apple trees grafted on M.26.

\begin{tabular}{|c|c|c|c|c|c|c|c|}
\hline \multirow{3}{*}{$\begin{array}{l}\text { Planting density } \\
\quad \text { (trees/ha) }\end{array}$} & \multirow{3}{*}{$\begin{array}{l}\text { Depth from } \\
\text { ground }(\mathrm{cm})\end{array}$} & \multicolumn{6}{|c|}{ Dry wt. of root $(\mathrm{kg} / \mathrm{tree})^{\mathrm{z}}$} \\
\hline & & \multicolumn{4}{|c|}{ Diameter of root (mm) } & \multirow{2}{*}{ Root crown } & \multirow{2}{*}{ Total } \\
\hline & & $<1$ & $1-5$ & $5-15$ & $>15$ & & \\
\hline \multirow[t]{5}{*}{623} & $0 \sim 30$ & 1.54 & 1.93 & 2.56 & 5.30 & 2.86 & $14.19(78.6)^{y}$ \\
\hline & $30 \sim 60$ & 0.65 & 1.27 & 0.55 & 0.37 & - & $2.84(15.7)$ \\
\hline & $60 \sim 90$ & 0.19 & 0.52 & 0.05 & - & - & $0.76(4.2)$ \\
\hline & $90 \sim 120$ & 0.09 & 0.18 & - & - & - & $0.27(1.5)$ \\
\hline & Total & $2.47(13.7)$ & $3.90(21.6)$ & $3.16(17.5)$ & $5.67(31.4)$ & $2.86(15.8)$ & $18.06(100)$ \\
\hline \multirow[t]{5}{*}{1185} & $0 \sim 30$ & 0.93 & 1.37 & 1.44 & 3.25 & 1.78 & $8.77(76.5)$ \\
\hline & $30 \sim 60$ & 0.34 & 0.72 & 0.62 & 0.21 & - & $1.89(16.5)$ \\
\hline & $60 \sim 90$ & 0.17 & 0.35 & 0.08 & - & - & $0.60(5.2)$ \\
\hline & $90 \sim 120$ & 0.07 & 0.14 & - & - & - & $0.21(1.8)$ \\
\hline & Total & $1.51(13.2)$ & $2.58(22.5)$ & $2.14(18.6)$ & $3.46(30.2)$ & $1.78(15.5)$ & $11.47(100)$ \\
\hline \multirow[t]{5}{*}{3178} & $0 \sim 30$ & 0.50 & 0.72 & 0.71 & 1.26 & 0.89 & $4.08(72.1)$ \\
\hline & $30 \sim 60$ & 0.25 & 0.30 & 0.23 & 0.17 & - & $0.95(16.8)$ \\
\hline & $60 \sim 90$ & 0.08 & 0.33 & 0.08 & - & - & $0.49(8.6)$ \\
\hline & $90 \sim 120$ & 0.04 & 0.10 & - & - & - & $0.14(2.5)$ \\
\hline & Total & $0.87(15.4)$ & $1.45(25.6)$ & $1.02(18.0)$ & $1.43(25.3)$ & $0.89(15.7)$ & $5.66(100)$ \\
\hline
\end{tabular}

Values are means of two trees.

${ }^{z}$ Digging of root system was carried out in early June late July, 1986. Digging area is a quadrangle enclosed by the midline between tree rows and the midline between trees within a row. Roots were gathered from the soil at $0 \sim 30,30 \sim 60,60 \sim 90$ and 90 120 cm depths. Roots at each depth were divided into diameter classes $(<1 \mathrm{~mm}, 1$ to $5 \mathrm{~mm}, 5$ to $15 \mathrm{~mm}$ and $>15 \mathrm{~mm})$ and then they were washed, dried at $80^{\circ} \mathrm{C}$ for one week and weighed. y Values of parenthesis are the percentage of the total values. 
培に打ける密度効果則の適用は, 将来の課題である.

\section{1樹当たり根重と栽植密度のロジスチック関係}

1 樹当たり根重は各台木樹とも, 栽植密度の増加に 伴って減少した (第 3 表)。同様の結果は, Atkinson ら （1976）女報告して扣り，根成長に関する密度効果の一般 的現象と考えられる.

また，栽植密度の増加に伴ら 1 樹当たり根重の抑制率 （(623 樹/ha 区の 1 樹当たり根重 -3178 樹/ha 区の 1 樹当

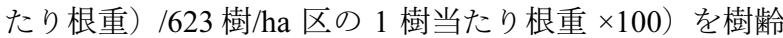
12 年生の M.9 と MM.106 台木樹において計算すると, それぞれ 60.4\% と 72.4\% となり，MM.106 台木樹のよう な，わい化度の弱い台木樹で抑制率が高く，密度効果が 強く現れることが示された.

以上のような 1 樹当たり根重と栽植密度の関係をロジ スチック理論に基づいて解析した。 その結果， 1 樹当た り根重の逆数 $(1 / R)$ と栽植密度 $(\rho)$ との間には, 各台木 樹とも正の高い相関係数が得られ，次のよらな逆数式の 成立が認められた（第 3 図）.

$$
1 / \mathrm{R}=\mathrm{A}_{\mathrm{R}} \rho+\mathrm{B}_{\mathrm{R}}
$$

ただし， $A_{R}$ と $B_{R}$ は樹齢や台木によって変化する係数.

逆数式（1）は， $\mathrm{R}$ と $\rho$ を両側対数目盛でプロットす ると, 十分に栽植密度が低いと 1 樹当たり根重は栽植密 度に関係なく一定であるが，ある程度以上栽植密度が高
くなると根の成長が抑えられることを示している．この 場合， 1 樹当たり根重の抑制が急になる栽植密度，すな わち密度効果が著しくなる栽植密度 $\left(\rho_{\mathrm{Rspec}}\right)$ は, 次式で

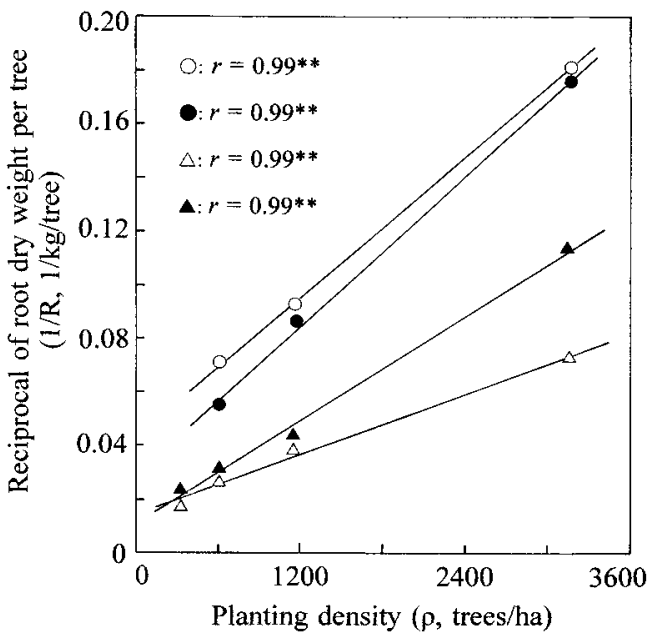

Fig. 3. Linear regression between reciprocal of root dry weight per tree $(1 / R)$ and planting density $(\rho)$ in 'Starking Delicious' apple trees grafted on M.9, M.26, M.7 and MM.106. O, M.9 trees (12year-old); , M.26 trees (11-year-old); $\triangle$, M.7 trees (13-yearold); $\boldsymbol{\Delta}$, MM.106 trees (12-year-old). ${ }^{* *}$ Significant at the $1 \%$ level.

Table 3. Effect of planting density on trunk cross-sectional area (TCA), root dry weight per tree and per hectare in 'Starking Delicious' apple trees grafted on dwarfing and semi-dwarfing rootstocks.

\begin{tabular}{|c|c|c|c|c|c|}
\hline Root stock & Age (ys) & $\begin{array}{l}\text { Planting density } \\
\text { (trees/ha) }\end{array}$ & $\mathrm{TCA}^{\mathrm{z}}\left(\mathrm{cm}^{2} /\right.$ tree $)$ & $\begin{array}{c}\text { Dry wt. of root } \\
\text { per tree }(\mathrm{kg} / \text { tree })\end{array}$ & $\begin{array}{c}\text { Dry wt. of root } \\
\text { per hectare }^{\mathrm{x}}(\mathrm{t} / \mathrm{ha})\end{array}$ \\
\hline \multirow[t]{3}{*}{ M.9 } & 12 & 623 & $96.29 \mathrm{a}^{\mathrm{u}}$ & $13.94 \mathrm{a}$ & $8.68 \mathrm{~b}$ \\
\hline & & 1185 & $82.46 \mathrm{a}$ & $10.73 \mathrm{a}$ & $12.72 \mathrm{ab}$ \\
\hline & & 3178 & $52.34 \mathrm{~b}$ & $5.52 \mathrm{~b}$ & $17.54 \mathrm{a}$ \\
\hline Significance $^{\mathrm{w}}$ & & & * & $*$ & $*$ \\
\hline \multirow[t]{3}{*}{ M.26 } & 11 & 623 & $144.60 \mathrm{a}$ & $18.06 \mathrm{a}$ & $11.25 b$ \\
\hline & & 1185 & $102.95 \mathrm{ab}$ & $11.47 \mathrm{~b}$ & $13.59 \mathrm{~b}$ \\
\hline & & 3178 & $60.00 \mathrm{~b}$ & $5.66 \mathrm{c}$ & $17.99 \mathrm{a}$ \\
\hline Significance & & & $*$ & $* *$ & $*$ \\
\hline \multirow[t]{4}{*}{ M.7 } & 13 & 330 & $282.56 \mathrm{a}$ & $50.03 \mathrm{a}$ & $16.51 \mathrm{c}$ \\
\hline & & 623 & $211.75 b$ & $38.02 \mathrm{~b}$ & $23.69 \mathrm{c}$ \\
\hline & & 1185 & $160.19 b$ & $25.51 \mathrm{c}$ & $30.23 b$ \\
\hline & & 3178 & $96.27 \mathrm{c}$ & $13.41 \mathrm{~d}$ & $42.62 \mathrm{a}$ \\
\hline Significance & & & $* *$ & $* *$ & $* *$ \\
\hline \multirow[t]{4}{*}{ MM.106 } & 12 & 330 & $242.30 \mathrm{a}$ & $41.01 \mathrm{a}$ & $13.53 b$ \\
\hline & & 623 & $190.97 \mathrm{ab}$ & $31.25 b$ & $19.47 \mathrm{ab}$ \\
\hline & & 1185 & $151.29 \mathrm{~b}$ & $22.45 \mathrm{c}$ & $26.60 \mathrm{a}$ \\
\hline & & 3178 & $66.40 \mathrm{c}$ & $8.62 \mathrm{~d}$ & $27.39 \mathrm{a}$ \\
\hline Significance & & & $*$ & $* *$ & $*$ \\
\hline
\end{tabular}

Values are means of two trees.

${ }^{\mathrm{z}}$ Measured at $20 \mathrm{~cm}$ above the graft union in October of 1985 for trees on M.26, 1986 for trees on M.9 and MM.106 and 1987 for trees on M.7.

y Digging of root system was carried out in June-July 1986 for trees on M.26, June-July 1987 for trees on M.9 and MM.106 and June 1988 for trees on M.7. At each planting density digging area and depth are the same as Table 2.

${ }^{x}$ Calculated as: root dry weight per tree $\times$ planting density.

" Significant at the $5 \%(*)$ and $1 \%(* *)$ by the $\mathrm{F}$ analysis.

"Different letters represent significant differences $(P<0.05)$ by Duncan's multiple range test. 
表される (Shinozaki・Kira, 1961).

$$
\rho_{\mathrm{Rspec}}=\mathrm{B}_{\mathrm{R}} / \mathrm{A}_{\mathrm{R}}
$$

この式で同一樹齢の M.9 と MM.106 樹における $\rho_{\text {Rspec }}$ を計算すると，M.9 台木樹では 1009 樹/ha, MM.106 樹 では 331 樹/ha が得られる。この結果は, MM.106 台木 樹の 1 樹当たり根重に関する密度効果が M.9 台木樹より 約 3 倍早く進んだことを示している. 前述のわい化度が 弱い台木樹臣ど密度効果が強く現れるといら事実は，式 （2）によっても立証される.

\section{1樹当たり根重と幹断面積の相対成長関係}

幹断面積 $(\theta)$ と 1 樹当たり根重 $(R)$ における相対成長 関係を第 4 図に示した. $\theta$ の常用対数值と $\mathrm{R}$ の常用対数 值との間には，各台木樹とも高い相関係数が得られ，相 対成長係数 $h>1$ をもつ次の相対成長式の成立が認めら れた（第 4 表）.

$$
\mathrm{R}=\mathrm{H} \theta^{\mathrm{h}}
$$

ただし，H は台木によって変化する係数.

幹断面積と部分重との間における相対成長係数 $\mathrm{h}$ は, 器官固有の值として，果実重では h>1（黒田ら，1997）, 葉重では $\mathrm{h} \fallingdotseq 1 （$ 黑田・千葉，1999）, 幹重では $\mathrm{h}<1$ （黒 田・千葉，2004），枝重では $\mathrm{h} \fallingdotseq 1 （$ 黑田・千葉，2004） の值が得られている. 本試験の根重の場合は $\mathrm{h}>1$ で, 果 実重と同様の相対成長係数を示すことがわかった。 した がって，リンゴ樹の根重は果実重と同様に，全体重に占 める割合が高いといら特性を有しているものと考えられ る.

森林樹木では幹断面積や幹直径などから，相対成長関 係を利用して，各器官の乾重推定が行われているが，こ の推定法の適用には相対成長関係が年によって変化しな いことが条件とされている（依田，1971）。そこで，この 点を確かめるために, 樹齢 12 年生と 13 年生の M.9 台 木樹に扣ける幹断面積と 1 樹当たり根重の相対成長関係 を調べた. その結果，12 年生と 13 年生を込みにした幹 断面積と 1 樹当たり根重の相対成長関係は，高い相関係 数 $(r=0.99,1 \%$ 水準で有意）で，同一回帰線上に乗る ことが認められ (データ省略), 幹断面積と 1 樹当たり 根重の相対成長関係は 2 年程度の期間では変化しないい ことが示された。したがって，1 樹当たり根重は現存量 調査の前後 1 年以内であれば，式（3）に幹断面積を代
入することにより推定可能と考えられる.

\section{1 ha 当たり根重の垂直分布に及ぼす栽植密度の影響}

第 5 図は, 第 2 表の 1 樹当たり根重の垂直分布を 1 ha 当たりに換算して示したものである. 1 ha 当たり根重の 垂直分布は 1 樹当たりのそれと異なり，各層とも栽植密 度の増加に伴って増加することが認められた。 このこと は, Atkinson ら（1976）と Kaufmann ら（1972）が述べ ているように，栽植密度の増加に伴って根密度が増加し た結果と考えられる.

また，栽植密度の増加に伴う根重増加を太さ別でみる と, 各層とも高密度区で小・細根の増加が目立っていた. Atkinson（1978）によると，高密度区のリンゴ樹は養水 分の吸収量が多く，養水分不足が起こりやすいとされて いる. 養水分の吸収は主に小・細根からの根毛が担って いるので，高密度区で小・細根が多いのは，制限された 占有面積下で養水分を効率的に吸収するための適応的な 現象と考光られる.

6. 1 ha 当たり根重と栽植密度のロジスチック関係

1 ha 当たり根重は 1 樹当たり根重とは逆に, 各台木樹 とも栽植密度の増加に伴って増加した（第 3 表）。この

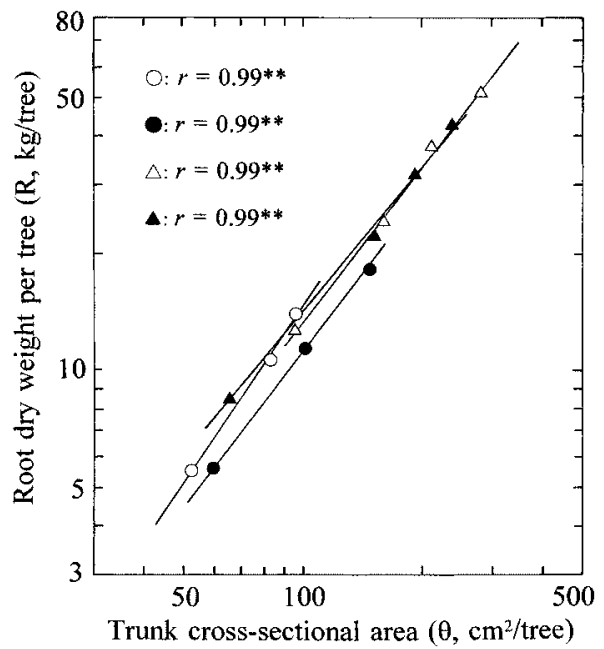

Fig. 4. Relative growth relationship between root dry weight per tree $(\mathrm{R})$ and trunk cross-sectional area $(\theta)$ in 'Starking Delicious' apple trees grafted on M.9, M.26, M.7 and MM.106. The symbols are the same as Fig. 3. ${ }^{* *}$ Significant at the $1 \%$ level.

Table 4. Characteristic values of logistic growth of root dry weight per tree and trunk cross-sectional area (TCA), and relative growth of root dry weight per tree in 'Starking Delicious' apple trees grafted on dwarfing and semi-dwarfing rootstocks.

\begin{tabular}{cccccccc}
\hline \hline Rootstock & Age (ys) & $\mathrm{A}_{\mathrm{R}}{ }^{\mathrm{z}}$ & $\mathrm{B}_{\mathrm{R}}{ }^{\mathrm{z}}$ & $\mathrm{H}^{\mathrm{y}}$ & $\mathrm{h}^{\mathrm{y}}$ & $\mathrm{A}^{\mathrm{x}}$ & $\mathrm{B}^{\mathrm{x}}$ \\
\hline M.9 & 12 & 0.0000432 & 0.0436 & 0.0141 & 1.5067 & 0.0000034 & 0.0082 \\
M.26 & 11 & 0.0000468 & 0.0286 & 0.0256 & 1.3181 & 0.0000037 & 0.0049 \\
M.7 & 13 & 0.0000190 & 0.0148 & 0.0462 & 1.2442 & 0.0000023 & 0.0031 \\
MM.106 & 12 & 0.0000326 & 0.0108 & 0.0538 & 1.2080 & 0.0000039 & 0.0026 \\
\hline
\end{tabular}

${ }^{2}$ Coefficients in the reciprocal equation (1) between reciprocal of root dry weight per tree and planting density.

${ }^{y}$ Coefficients in the relative growth equation (3) between root dry weight per tree and TCA.

${ }^{x}$ Coefficients in the reciprocal equation (4) between reciprocal of TCA and planting density. 


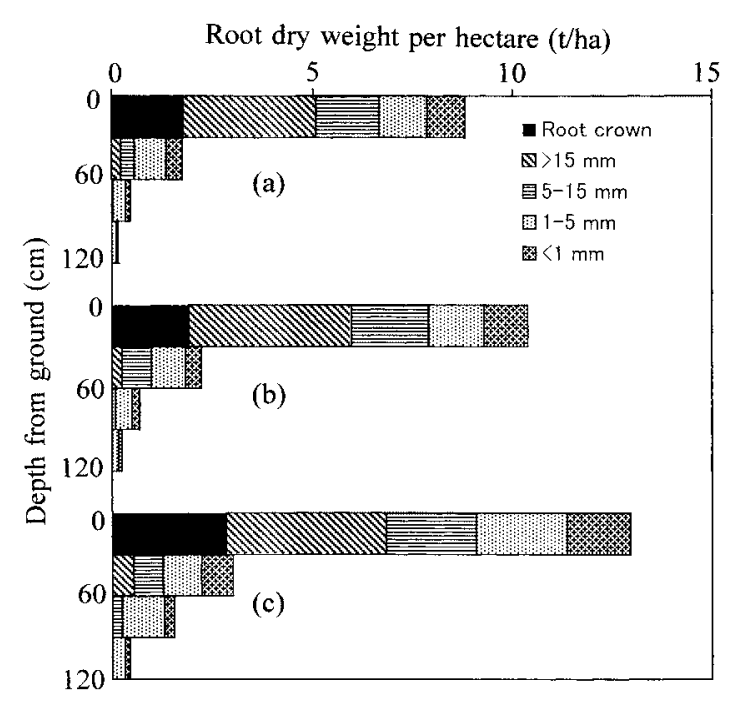

Fig. 5. Effect of planting density on vertical root distribution in 11year-old 'Starking Delicious' apple trees grafted on M.26. Based on the data shown in Table 2, root dry weight per hectare at each depth was calculated as: root dry weight per tree at each depth $\times$ planting density. (a), 623 trees/ha; (b), 1185 trees/ha; (c), 3178 trees/ha.

ような 1 ha 当たり根重と栽植密度の関係をロジスチック 理論に基づいて解析した.

まず，幹断面積 $(\theta)$ と栽植密度 $(\rho)$ の逆数関係につい て検討した結果， $1 / \theta$ と $\rho$ との間には, 各台木樹とも $1 \%$ 水準で有意な相関係数が得られ，次の逆数式の成立が認 められた (データ省略).

$$
1 / \theta=\mathrm{A} \rho+\mathrm{B}
$$

ただし，A と B は樹齢や台木によって変化する係数.

次に, 1 ha 当たり根重 $(\bar{R})$ は,

$$
\overline{\mathrm{R}}=\mathrm{R} \rho
$$

と定義されるので, 1 ha 当たり根重 $(\overline{\mathrm{R}})$ と栽植密度 $(\rho)$ の関係は，式（3)，(4) 拈よび（5）から,

$$
\overline{\mathrm{R}}=\mathrm{H} \rho /(\mathrm{A} \rho+\mathrm{B})^{\mathrm{h}}
$$

が導かれる.

$\mathrm{H}, \mathrm{h}, \mathrm{A}$ 打よび B は求められているので (第 4 表), 式 (6) の $\log \overline{\mathrm{R}} \sim \log \rho$ 曲線が描ける. 第 6 図は，樹齢 12 年生の M.9 と MM.106 台木樹に打ける実測值に式 (6) で計算した曲線をあてはめたものである. 両台木樹とも, 式（6）で描いた曲線は実測值の動きを良くあらわし，式 (6) が 1 ha 当たり根重の密度効果式として適合性の高い

\section{ことが認められた.}

また，第 6 図からは，1 ha 当たり根重を最大にする栽 植密度 $\left(\rho_{\overline{\mathrm{R}} \mathrm{pk}}\right)$ が存在することがわかる。 $\rho_{\overline{\mathrm{R}} \mathrm{pk}}$ の存在は, 相対成長係数 $\mathrm{h}>1$ から予測できるが(穂積・篠崎, 1960), その值は式 (6) の微分形 $=0$ から得られる次式で与えら れる.

$$
\rho_{\overline{\mathrm{R} p k}}=\mathrm{B} / \mathrm{A}(\mathrm{h}-1)
$$

以上の結果から，1 ha 当たり根重は栽植密度の増加に

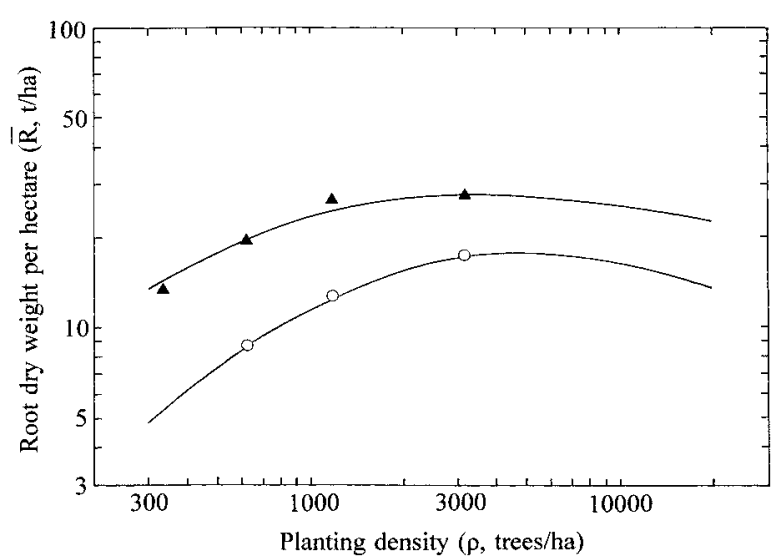

Fig. 6. Relationship between root dry weight per hectare $(\overline{\mathrm{R}})$ and planting density $(\rho)$ of 12-year-old 'Starking Delicious' apple trees grafted on M.9 $(\bigcirc)$ and MM.106 ( $\mathbf{\Delta})$. The $\log \bar{R} \sim \log \rho$ relations on each rootstock are well fitted by the curves given by $\overline{\mathrm{R}}=\mathrm{H} \rho /(\mathrm{A} \rho+\mathrm{B})^{\mathrm{h}}$ (equation 6).

伴って増加するが， $\rho_{\overline{\mathrm{R}} \mathrm{pk}}$ を境にして減少に転じることが 明らかになった。 また，式（7）によって樹齢 12 年生の M.9 と MM.106 台木樹の $\rho_{\overline{\mathrm{R} p k}}$ を計算すると，それぞれ 4760 樹/ha と 3205 樹/ha が得られ，わい化度の弱い台木 樹汪ど $\rho_{\overline{\mathrm{R} p k}}$ が早く減少することが示された.

ところで, 式 (6) で表される根の現存量と栽植密度の 関係は, 高密度域で一定化する枝の現存量や栽植密度の 増加に伴って増加し続ける幹の現存量 (黒田・千葉, 2004) と明らかに相違していた。枝幹成長に関する密度効果に ついては，既にパイプ・モデル説（Shinozaki ら，1964） によって解釈できることを報告した（黒田・千葉, 2004). このような密度効果の生態学的解釈は, 根の密度効果に もあてはまるものと考光られる。 そこで，以下では，根 成長に関する密度効果の生態学的解釈について考察する ことにする。

\section{7. 根の成長に関する密度効果の生態学的解釈}

リンゴ樹は忌地現象を起こす植物であり，その原因物 質は根皮から分泌される phlorigin の分解物であるとさ れている (Börner，1960). したがって， $\rho_{\overline{\mathrm{R} p k}}$ で根の現存 量が低下し始めるのは，他感作用が関与している可能性 が考光られる，事実，平野・中井（1966）は高密植の乇 モ樹に打いて，根の現存量が時間の経過に伴って減少す ることを認め，その原因が根から分泌される毒物質であ ることを報告している.

一方，植物はある限度以上の密度になると，個体間の 競り合いにより劣勢個体が自然に間引か机る，いわゆる 自己間引きを起こすことが知られている（依田，1971）. しかし, 本試験の高密度域では, 背揃い現象（黒田・千 葉，2000）や根の組織的融合など助け合い的な現象は久 られたものの，自己間引きを起こすような競り合い現象 はみられなかった．Koyama・Kira（1956）はダイズ個体 群に执いて，高密度状態でも自己間引きが起こり難い例 
を観察し，このような個体群は大雨によって一斉に倒伏 し，個体群が崩壊したことを報告している。一般に，自 己間引きを起こさない個体群は共倒れ型個体群と呼ば れ，環境に対する抵抗性が弱いとされている（小川, 1980). 本試験でも， $6 〜 7$ 月が低温・寡日照であった年 に，高密度域の個体群では純生産量が著しく低下し，悪 い環境に対して脆弱であったことが認められている（黒 田ら, 1996).

以上のことから, 1 ha 当たり根重が $\rho_{\overline{\mathrm{R}} \mathrm{pk}}$ を境に減少に 転じるのは, リンゴ個体群が共倒れ型個体群としての生 態的特性を有していることに起因し，その生態的特性は 根分泌物由来の他感作用によるものと考兄られる。すな わち, 栽植密度が増加すると, 根密度の増加に伴って根 分泌物が蓄積し，やがて根成長の阻害が始まる栽植密度 に達する。この栽植密度が $\rho_{\overline{\mathrm{R}} \mathrm{pk}}$ であって，この密度か ら根の現存量が低下し始め, 個体群の生育がしだいに脆 弱化していくものと考兄られる.これが式（6）が示す根 成長に関する密度効果の生態学的解釈である。このよう に考兄ると, 前述の M.9 と MM.106 台木樹における $\rho_{\bar{R} \mathrm{pk}}$ の差は，容易に理解できる。つまり，MM.106 台木樹の $\rho_{\overline{\mathrm{Rpk}}}$ が M.9台木樹のそれより低かったのは, MM.106台木 樹の根成長が M.9 台木樹より抢ら盛なため（第 3 表）, その分，他感作用が早く現れた結果と考光られる.

わが国のリンゴわい化栽培では， $\rho_{\overline{\mathrm{R}} \mathrm{pk}}$ のような高密度 での栽植様式は実在しないため, $\rho_{\overline{\mathrm{R}} \mathrm{pk}}$ が問題になるよう なことはない，しかし，西ヨーロッパ諸国では，70000 樹/ha 植えのメドーオーチャードや 4000〜 8889 樹/ha 植 壳の超高密植栽培が重要な研究課題として検討されてい る (Jackson，1989). 将来，このような超高密植栽培が実 現した段階では， $\rho_{\overline{\mathrm{R} p k}}$ が問題になってくるかもしれな い.

\section{摘 要}

無剪定状態で管理した樹齢11〜13年生のわい性および 半わい性台木を利用したリンゴ‘スターキング・デリシャ ス’ 樹を用いて, 根の成長に及ぼす栽植密度の影響につ いて検討した．330樹/ha区の根系は太い側根と下垂根で 構成されていたが，3178樹/ha区では主に側根であった。 根系幅は栽植密度の増加に伴って減少したが，隣接樹の 根系に抢ける交差深度は増加した. 3178樹/ha区では隣接 樹の根系間で根組織の癒着現象が観察された。根系幅 / 樹冠幅比は栽植密度の増加に伴って減少し, 根系幅の方 が樹冠幅より密度効果を受けやすいことが示された．根 重の垂直分布比率は栽植密度による影響が認められな かったが，1樹当たり根重は各層とも栽植密度の増加に 伴って減少し，その減少は0～ $30 \mathrm{~cm}$ 層の大根で著しかっ た。1樹当たり根重 $(R)$ は各台木樹とも，栽植密度 $(\rho)$ の増 加に伴って減少した． $\mathrm{R}$ と $\rho$ の関係は, 次の逆数式に よって表された。
$1 / R=A_{R} \rho+B_{R}$ ただし， $A_{R}$ と $\mathrm{B}_{\mathrm{R}}$ は樹齢や台木によって変化する係数. 幹断面積 $(\theta)$ と 1 樹当たり根重 $(\mathrm{R})$ の関係は各台木樹と も， $\mathrm{h}>1$ である次の相対成長式で表された.

$\mathrm{R}=\mathrm{H} \theta^{\mathrm{h}}$ ただし， H は台木によって変化する係数. 1 ha 当たり根 重は 1 樹当たり根重と異なり, 各層とも栽植密度の増加 に伴って増加し，その増加は小・細根で顕著であった。 1 ha 当たり根重 $(\bar{R})$ は各台木樹とも, 栽植密度 $(\rho)$ の増 加に伴って増加した. $\overline{\mathrm{R}}$ と $\rho$ の関係は, 式 (3)の $\mathrm{R}=\mathrm{H} \theta^{\mathrm{h}}$, 式（4）の $1 / \theta=\mathrm{A} \rho+\mathrm{B}$ 战よび式（5）の $\overline{\mathrm{R}}=\mathrm{R} \rho$ から導か れる式（6）によく当てはまった. $\overline{\mathrm{R}}$ を最大にする栽植密 度 $\left(\rho_{\overline{\mathrm{R} p k}}\right)$ は式（7）で与兄られる。

$$
\begin{aligned}
& \overline{\mathrm{R}}=\mathrm{H} \rho /(\mathrm{A} \rho+\mathrm{B})^{\mathrm{h}} \\
& \rho_{\overline{\mathrm{R} p k}}=\mathrm{B} / \mathrm{A}(\mathrm{h}-1)
\end{aligned}
$$

ただし，A と B は樹齢や台木によって変化する係数．以 上の結果から, 1 ha 当たり根重は栽植密度の増加に伴っ て増加するが， $\rho_{\overline{\mathrm{R} p k}}$ において減少に転じることが示され た。

謝 辞 本試験の実施に際して，多大のご援助を頂い た元農林水産省北海道農業試験場技官の佐藤忠治氏，谷

口諒氏扣よび田中久夫氏に深く感謝の意を表します。

\section{引用文献}

Atkinson, D. 1978. The use of soil resources in high density planting systems. Acta Hort. 65: 79-89.

Atkinson, D., D. Naylor and G. A. Coldrick. 1976. The effect of tree spacing on the apple root system. Hort. Res. 16: $89-105$.

Börner, H. 1960. Liberation of organic substances from higher plants and their role in the soil sickness problem. Bot. Rev. 26: 393-424.

Boswell, S. B., C. D. McCarty and L. N. Lewis. 1975. Tree density affects large-root distribution of 'Washington' navel orange trees. HortScience 10: 593-595.

Coker, E. G. 1958. Root studies. XII. Root systems of apple on Malling rootstocks on five soil series. J. Hort. Sci. 33: 71-79.

平野 暁・中井滋郎，1966，果樹を密植した場合に打け る根分泌物の影響. 園学雑. 35: 1-7.

穂積和夫・吉良竜夫・篠崎吉郎. 1958. クサフヨウの生 長に打上活す光の強さと個体密度の影響. ふたつの 線型生長要因間の相互作用を中心とした解析．生理 生態. 8: 36-49.

穂積和夫・篠崎吉郎. 1960. 植物生長のロジスチック理 論. p. 272-304. 吉良竜夫編著. 生態学体系 2 上. 古 今書院. 東京.

Jackson, H. E. 1989. World-wide development of high density planting in research and practice. Acta Hort. 243: 17-27. 
Kaufmann, M. R., S. B. Boswell and L. N. Lewis. 1972. Effect of tree spacing on root distribution of 9-year old 'Washington' navel oranges. J. Amer. Soc. Hort. Sci. 97: 204-207.

Koyama, H. and T. Kira. 1956. Intraspecific competition among higher plants. VIII. Frequency distribution of individual plant weight as affected by the interaction between plants. J. Inst. Polytech. Osaka City Univ. D7: 73-94.

黒田治之・千葉和彦. 1999. わい性および半わい性台木 利用リンゴ樹の葉量生長に及ぼす栽植密度の影響. 園学雑. 68: 312-320.

黒田治之・千葉和彦. 2000. わい性および半わい性台木 利用リンゴ樹における花芽形成に及ぼす栽植密度の 影響. 園学雑. 69: 298-307.

黒田治之・千葉和彦. 2002. M.26 わい性台木利用リンゴ 樹における生産構造および光環境に及ぼす栽植密度 の影響. 園学雑. 71: 544-552.

黒田治之・千葉和彦. 2004. わい性および半わい台木利 用リンゴ樹に扣ける枝幹成長と栽植密度との関係. 園学雑. 73: 250-258.
黒田治之・千葉和彦・西山保直. 1997. わい性扎よび半 わい性台木利用リンゴ樹に拈ける栽植密度と果実収 量の関係. 園学雑. 66: 35-43.

黒田治之・西山保直・千葉和彦. 1996. わい性拈よび半 わい性台木利用リンゴ樹に拈ける栽植密度と生長の 関係. 園学雑. 65: 227-236.

三浦小四郎. 1950. 樹形を異にせる苹果樹の根群. 園学 雑. 19: 85-88.

小川房人. 1980 . 個体群の構造と機能（植物生態学講座 5)。朝倉書店. 東京.

Shinozaki, K. and T. Kira. 1956. Intraspecific competition among higher plants. VII. Logistic theory of C-D effect. J. Inst. Polytech. Osaka City Univ. D7: 35-72.

Shinozaki, K. and T. Kira. 1961. The C-D rule, its theory and practical uses. J. Biol. Osaka City Univ. 12: 69-82.

Shinozaki, K., K. Yoda, K. Hozumi and T. Kira. 1964. A quantitative analysis of plant form-The pipe model theory. I. Basic analyses. Jap. J. Ecol. 14: 97-105. 依田恭二. 1971. 森林の生態学. 築地書房. 東京. 